\title{
Virus-Like Microfossils in the 1.64 Ga Siliceous Rocks From Hogland Island, Russia
}

\author{
Anatoly. M. Belyaev ${ }^{1,2}$, Paul V. Yukhalin² \\ full members of the Paleontological Society of the Russian Academy of Sciences
}

\begin{abstract}
1 Institute of Earth sciences, St. Petersburg State University, 199034, St. Petersburg, Universitetskaya nab., 7-9, Russia

Email: paleovirusology@mail.ru; a.beliaev@spbu.ru; abel-7-777@yandex.ru https://orcid.org/0000-0001-7035-7521; http://www.paleovirusology.ru/

2 Paleovirusology group, Sidose LLC, St. Petersburg, Russia

Email: paleovirusology@mail.ru
\end{abstract}

\section{Abstract}

Several varieties of virus-like microfossils, morphologically similar to modern giant viruses of the Mimiviridae family, have been identified in microquartzites in the $1.64 \mathrm{Ga}$ volcanogenicsedimentary strata in Hogland Island in the Gulf of Finland, Russia. Microquartzites contain graphite enriched in a light carbon isotope ${ }^{12} \mathrm{C}$, as is typical for the rocks forming with participation of living matter. Abundant remains of silificated and ferruginizated microfossils of planktonic microorganisms and virus-like structures were found in fragments of silificated biofilms. However, virus-like microfossils exceed modern giant viruses in linear dimensions by a factor of a thousand or more (Belyaev, 2018; 2019; Belyaev, Yukhalin, 2021) and contain structures similar to eukaryotic nuclei. In addition, data were obtained that can be interpreted as a fact of parasitic relationships of virus-like formations with microfossils of amoeba-like microorganisms. Inside, and in the immediate surroundings of some virus-like structures, small oval zonal formations occur, which, possibly, represent silificated viral particles, the most ancient obligate super parasites similar to "satellite" virophages in mimiviruses (La Scola, et al., 2008). Apatite grains found in the mineralized cytoplasm and nuclei of virus-like microfossils, most likely, crystallized from phosphoric acid residues of decayed nucleotides. This allowed for the first time to roughly estimate the size of the genomes of the most ancient virus-like structures, which exceeded the genomes of modern giant viruses and unicellular organisms by a factor of thousands (Belyaev, Yukhalin, 2021). The genome masses of eukaryotic microfossils and virus-like structures were also estimated following the principle of genomic-nuclear proportionality, according to which the molecular weights of genomes are directly proportional to the size of the nuclei. In this case, the size of genomes of virus-like structures estimated both form the enclosed apatite grains and the size of nuclei, averaged tens of thousands of picograms and, thus, could contain tens of thousands billions of base pairs. It is assumed that microfossils of virus-like structures from the group of unclear systematic position Dinoviridae Incertae sedis were representatives of the extinct family of unicellular facultative parasites or were the ancestors of giant viruses of the Mimiviridae family.

Key words: viruses, eukaryote genomes, Paleoproterozoic microfossils, siliceous rocks, carbon isotopes, underwater volcanism.

\section{INTRODUCTION}

The study of the origin and evolution of viruses is especially relevant in connection with the global pandemic that has affected almost the entire humanity. Every inhabitant of the Earth had repeated contacts and constant problems associated with these representatives of the living world. Viruses affect all types of cells and are the most abundant biological forms on Earth (Canchaya et al., 2003). Possibly, viral pandemics led to the extinction of many species of living organisms, and, thereby, influenced the evolution course of the biosphere. In addition, viruses are believed to be 
important natural means of gene transfer between different species contributing to their evolution and genetic diversity (Canchaya et al., 2003).

According to modern hypotheses, viruses could appear simultaneously with living organisms or originate from plasmids - particles of nucleotides that were able to move between cells. Viruses could appear in the process of evolution of small cells of facultative parasites, which with time lost the ability to reproduce independently and turned into obligate parasites - viruses (Legendre, 2012). The morphological and genetic diversity of viruses suggests that in the past they could form in different, independent ways.

Viruses exhibit a huge variety of shapes and sizes. Mature particles of enveloped viruses contain nucleic acids enclosed in protein coats - capsids. Among them, there are both simple spiral and spherical structures, and more complex ones, in the form of icosahedrons. Most of the viruses studied in the XX century have sizes ranging from 20 to $300 \mathrm{~nm}\left(1 \mathrm{~nm}=10^{-12} \mathrm{~cm}\right)$. However, in recent decades, several species of giant viruses of the Mimiviridae family were found (Abergel, et al., 2015; Arslan, et al., 2011; Jônatas Abrahão, et al., 2018). They are tens and hundreds of times larger than traditional viruses in linear dimensions. Mimivirus, Megavirus and Tupanvirus have capsids, which are similar in shape to icosahedrons and occur in sections as hexahedral or pentahedral zonal structures. Tupanvirus also has a long "tail" (Jônatas Abrahão et al., 2018). The genomes of Mimiviridae include both DNA and RNA and from one to one and a half million base pairs, which, respectively, have masses of about a million or more picograms (a 1 pg nucleotide contains 978 million base pairs). It is assumed that the ancestors of giant viruses could have a cellular structure and the ability to reproduce independently. Thus, the discoverers of giant Tupanvirus assume that it evolved from more complex unicellular organisms and in the process of transition to a parasitic lifestyle lost the ability to reproduce independently and lost some of its genes (Legendre, et al., 2012; Abergel, et al., 2015; Jônatas Abrah ão, et al., 2018).

However, despite the multitude and diversity of viruses and the role they played in the evolution of the biosphere, their genesis is not clear, since the fossilized remains of viruses have so far not been found in rocks and even in recent sediments. The absence of fossilized remains of viruses is due to the fact that they are actually tiny protein capsules that after death undergo postmortem transformations - lysis (dissolution) or collapse. At the same time, there is evidence of experimental silicification of viruses. Proteins and icosahedral capsids of the T4 bacteriophage heads are replaced by silica, which penetrates and precipitates in various viral structures (Laidler, et al., 2010). These studies suggest that the silificated viral microfossils may be found in rocks.

1. Conditions for fossilization of virus-like structures in siliceous rocks of Hogland Island

Non-skeletal microorganisms are best preserved in siliceous rocks forming from thermal, silica-saturated waters. Such rocks are known near modern thermal springs (Westall, et al., 1995; Benning, et al., 2002) as well as in volcanogenic-sedimentary strata (Belyaev, 2018; Belyaev, 2019; Belyaev, Yukhalin, 2021).

Hexahedral virus-like structures in association with microfossils of planktonic prokaryotes and eukaryotes were first found in siliceous rocks (microquartzites) occurring among lava sheets of basalts and rhyolites in Hogland Island in the Gulf of Finland. Earlier, geological studies had established that the basalts and rhyolites covers formed under conditions of underwater eruptions in a continental sea basin (Abel Sea), as evidenced by pillow structures in lavas characteristic of such environments (Belyaev, et al., 1998; Belyaev, 2018; Belyaev, Yukhalin, 2021). U-Pb isochronous dating of zircons from rhyolites was $1638 \pm 4$ and $1640 \pm 11$ Ma (Belyaev, et al., 1998), which coincides with $1640 \mathrm{Ma}$ ages of granites of the Wiborg rapakivi complex (Larin, 2011). Geochemical evidence also points to a significant enrichment of seawater with potassium due to juvenile fluids splitting off from the alkaline basaltic and rapakivi granite magmas (Belyaev, 2013; Belyaev, 2018).

Siliceous rocks in the form of lenticular interbeds among the basalts and rhyolites covers formed in the processes of interaction of magmatic melts with seawater. The erupting incandescent magmas heated the bottom waters to high temperatures and saturated them with ferrous ions, and an 
intense dissolution of silicon oxides occurred on the surface of the streams. After the ascent of lowdensity heated water to the upper horizons of the sea basin and its cooling, a silicon acid gel formed. It was deposited and accumulated in paleorelief lows on solidified volcanic rocks, often bordering pillow structures. Dark interbeds in microquartzites enriched in epidote formed during metamorphism of volcanic glass particles of ash material (Fig. 1.1.). Under the influence of heat of the overlying lava flows siliceous sediments underwent contact metamorphism turning into microquartzites composed of small crystals of quartz, chlorite and epidote. Clayey sediments turned into sericite schists consisting of fine-grained sericite potash mica (Belyaev, 2018; Belyaev and Yukhalin, 2021).

Bottom waters heated by lavas and saturated with silicon oxides and iron ions ascended to near-surface horizons of the basin, where they led to rapid fossilization (cilicification and ferruginization) of the planktonic assemblage of microorganisms together with mucous substance in which they coexisted. Silicon oxides from the mineralized solution penetrated the microorganisms and replaced the cytoplasm and organelles with opal or colloidal silica gel, while iron hydroxides precipitated on the walls of membranes and partitions, or formed a colloidal gel replacing the cytoplasm. Fragments of mineralized bacterial films and individual microfossils of silificated and ferruginizated microorganisms settled to the bottom and sank into siliceous and clayey sediments, together with which they underwent contact metamorphism.

2. Studies of isotopic composition of carbon from microquartzites were carried out at the Center for Isotope Research of the Russian Geological Research Institute on an elementary analyzer Flash EA 1112 (ThermoQuest, Milano, Italy), multi-collector mass-spectrometer DELTA ${ }^{\text {Plus }}$-XL (ThermoFinnigan, Germany) with a ConFlo III gas communicator (ThermoFinnigan, Germany). The results of four measurements showed that microquartzites from basalts and rhyolites contain graphite enriched in the light isotope ${ }^{12} \mathrm{C}\left(\delta^{13} \mathrm{C}=-27.1--29.5 \%\right)$. This indicates the presence of organic matter of biogenic origin in the siliceous rocks of Hogland Island, which is, apparently, associated with the presence of remains of planktonic microorganisms (Belyaev, 2018; Belyaev, Yukhalin, 2021).

\section{Microscopic examinations}

Microquartzites in basalts and rhyolites contain abundant remains of silificated and ferruginizated microfossils of planktonic microorganisms - prokaryotes and eukaryotes similar in morphology to recent coccoid and spiral-shaped cyanobacteria, amoebas, diatoms, foraminifers, flagellates, and multicellular organisms, which so far were unknown in rocks pf Paleoproterozoic age. Their description and photomicrographs are presented in previously published papers (Belyaev, 2018; Belyaev, 2019; Belyaev, Yukhalin, 2021). One should note a very important circumstance: the discovered microfossils are pseudomorphs by replacement that formed simultaneously with volcanic rocks 1,640 million years ago. Well-preserved outlines of microfossils, their internal structure and, most importantly, the undisturbed mutual arrangement of microorganisms in microquartzites and sericite schists, indicate that their fossilization (silicification and ferruginization) occurred contemporaneously with the surrounding mucous substance (biofilm). Therefore, it is possible to study not only the structural features of ancient microorganisms, but also their spatial relationships in the ecosystem of planktonic assemblages.

\section{Virus-like structures in microquartzites of Hogland Island}

Microfossils of ancient microorganisms with outer protein coats in the form of polyhedrons were first found in microquartzites in close association with the remains of silificated and ferruginizated microfossils of prokaryotes and eukaryotes (Belyaev, 2018). Polyhedral structures are similar in morphology to modern giant viruses of Mimiviridae family, and we consider them to be virus-like (VS). Also, data were obtained that can be interpreted as indicative of parasitic relationships of virus-like formations with microfossils of amoeba-like microorganisms. However, such features are not observed in all thin sections. Therefore, microfossils with hexagonal and pentahedral outer contours which, possibly, are sections of icosahedral outer envelopes are conventionally classified as virus-like structures. At the same time, fossil virus-like structures exceed modern giant viruses in linear dimensions by a factor of a thousand or more. In addition, 
these microfossils have signs of cellular structure and division, while, by definition, formations that do not have a cellular structure and are capable of reproduction only in the cells of living organisms can be called viruses. Therefore, in this work, the structures found are considered as virus-like within the group of unclear systematic position (Incertae sedis) with the provisional name Dinoviridae (Belyaev, 2018; Belyaev, Yukhalin, 2021).

4.1. Virus-like structures in microquartzites among basalts

Microquartzites among basalts formed due to contact metamorphism of: 1) siliceous sediments - Mk (Fig. 1.1); 2) silificated mucous substance of biofilms - Mk-1 (Fig. 1.2); 3) silificated cytoplasm of microorganisms and mucous substance surrounding the cells - Mk-0 (Figs. 1.2-1.5).

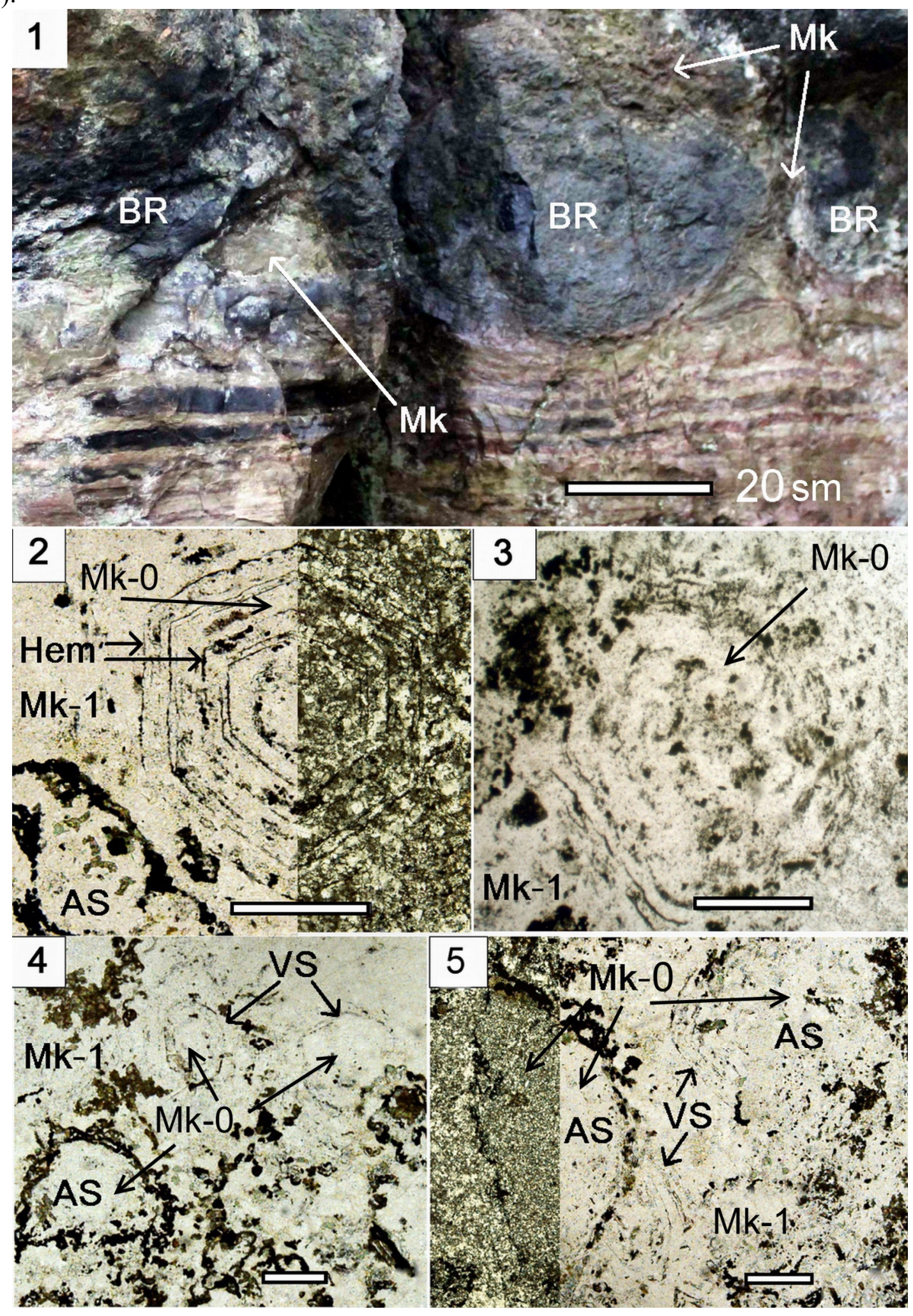


Fig. 1. Microquartzites in the basalts and microfossils of amoeba-like (AS), and virus-like (VS) structures. Microquartzites were formed on the: siliceous sediments - Mk, silificated of the biofilms mucosal substance - Mk-1, and cytoplasm of the planktonic microorganisms - Mk-0.

1.1. Pillows of basalt lavas (basaltic rocks - BR), surrounded by microquartzites (Mk), and lying on banded microquartzites (Mk).

1.2. Hexagonal zonal virus-like structure - VS in the Mk-1. External and internal contours VS and AS is composed by chains of hematite grains (Hem), and the Mk-0. At the bottom left is a fragment of an amoeba-like structures (AS). Thin sections, on the left part - without the analyzer, on the right part - with the analyzer.

1.3. «Wrinkled» VS composed by Mk-0, in microquartzites Mk-1 - dead virus? Thin section, without the analyzer.

1.4. Too virus-like VS in association with amoeba-like structures (AS) in the microquartzites Mk-1. Contours of the VS and AS is composed by chains of hematite grains (Hem), and the Mk-0. Thin sections, without the analyzer.

1.5. Fragments of contours of zonal virus-like structures (VS) in contact with amoeba-like structures (AS). Contours of the VS and AS is composed by chains of hematite grains (Hem), and the Mk-0. Thin sections, on the left - with the analyzer, on the right - without the analyzer.

In petrographic thin sections from microquartzites, hexagonal zonal formations were found, the inner and outer contours of which are composed of chains of small hematite grains (Hem). Mosaic structures of microquartzites (Mk-0) within the contours and in the surrounding groundmass are similar (Fig. 1.2.), which points to their simultaneous formation under similar physicochemical conditions. Hexagonal zonal structures are, possibly, sections of icosahedral envelopes of ancient virus-like formations. Hematite grains composing the contours, most likely, formed in the processes of recrystallization of iron hydroxides adsorbed on the membrane surface (Figs. 1.2.-1.5.). Among virus-like formations, there are also "shriveled" zonal formations, which, perhaps, represent pseudomorphs based on the remains of dead virus-like structures (Fig. 1.3.).

Ancient virus-like formations were in close association with structures that, with a certain degree of probability, can be considered as amoeba microfossils - AS (Figs. 1.2; 1.4; 1.5.). These structures have elongated or rounded outer contours $(0.5-2 \mathrm{~mm}$ across $)$ and are composed of chains of hematite, epidote, chlorite and graphite grains. It is possible that the shell minerals formed during metamorphism of particles from which the ancient amoebas built agglutinated shells.

There are fragments of zonal virus-like structures (VS) that are in direct contact with amoeba microfossils (Fig. 1.5). Possibly, these are pseudomorphs on residues of the protein substance of envelopes of the ancient virus-like structures that remained after their entry into cells.

In microquartzites of basalts, in close association with zonal virus-like formations, not only amoeba-like structures, but also numerous pseudomorphs occur morphologically similar to modern spiral and coccoid cyanobacteria and eukaryotes - diatoms and foraminifers (Belyaev, 2018). Most likely, cilicification and ferruginization of planktonic microorganisms occurred together with the biofilms in which they coexisted.

\subsection{Virus-like structures in microquartzites from rhyolite lavas}

Microquartzites in rhyolites lavas occur both as thin lenses, chemogenic siliceous sediments, and in cement of eruptive breccias in association with sericite schist (SS). Microquartzites formed both after siliceous sediments, and after silificated substance of biofilms - Mk-1. In this case, they display a wavy-striated texture showing up in interlacing of stripes of various shades often enveloping microfossils of cyanobacteria and eukaryotes (Fig. 2.1). Microquartzites Mk-1 have a characteristic reddish-brown color due to the finest admixtures of iron oxides (Figs. 2.1; 2.2). The silificated cytoplasm of planktonic microorganisms is also replaced by microquartzite (Mk-0). Sericite schists are composed of minor flakes of sericite mica (Figs. 2.2; 2.3; 2.4) formed during metamorphism of hydromicas in clayey sediments. 

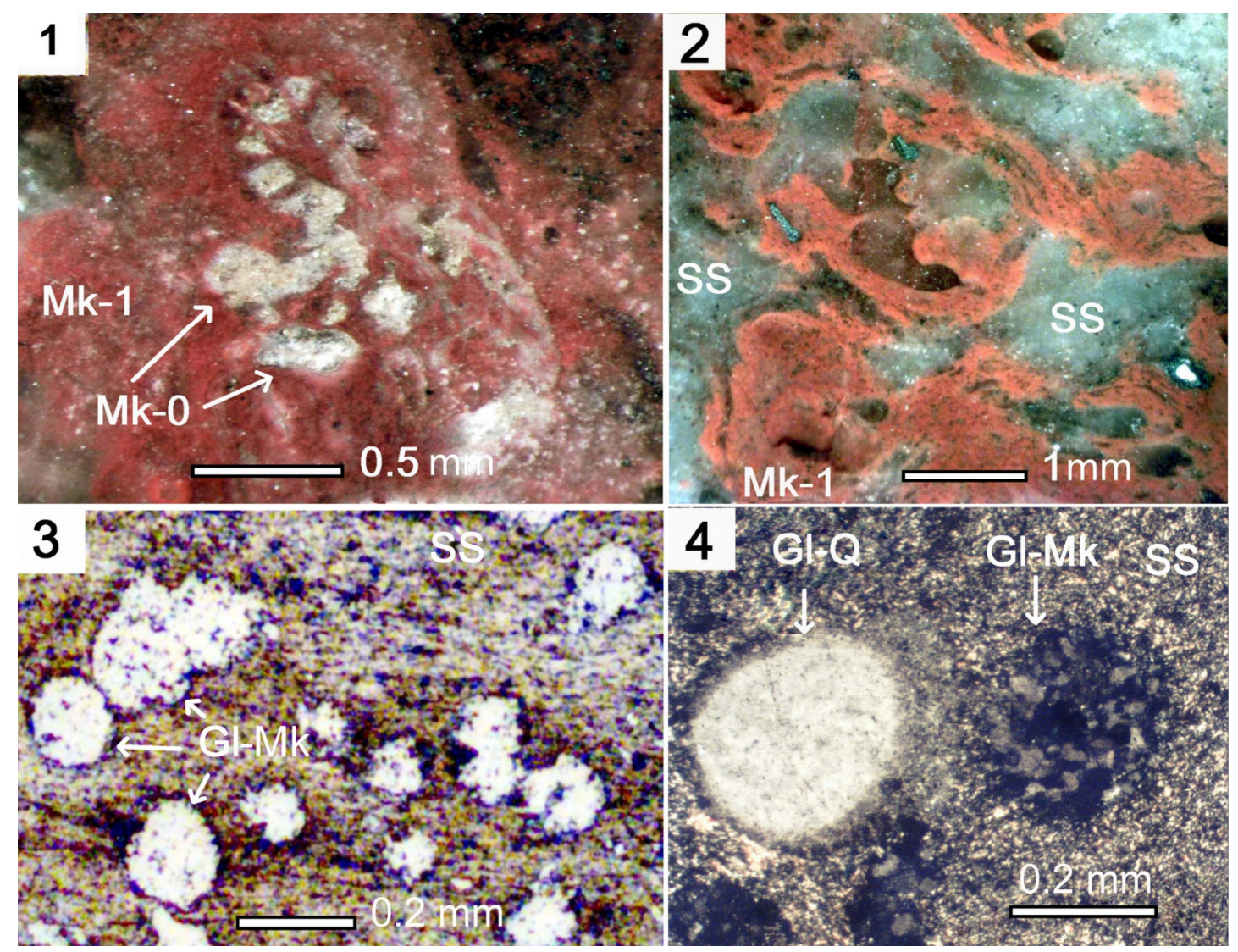

Fig. 2. Microquartzites and sericite shales

2.1. Microquartzites on the silificated mucous substance of biofilms (Mk-1) surrounding the cyanobacterium trichome (Mk-0). Polished specimen.

2.2. Fragments (Mk-1) with fibrous-trickle texture in the sericite shale SS. Polished specimen.

2.3. A Fragment, showing the texture of sericite shale (SS) with globules inclusions (G1). Thin section, without the analyzer.

2.4. A globules (Gl) of rounded grains of quartz and of microquartzites. Thin section, with the analyzer.

Sericite schists and microquartzites formed on the silificated mucous substance of biofilms (Mk-1) contain abundant foreign inclusions - rounded globules (Gl) to $0.5 \mathrm{~mm}$ across. They are represented by rounded quartz grains with a uniform extinction characteristic of quartz from rapakivi granites, and rounded microquartzite balls, in which quartz has a wavy (cloudy) extinction characteristic of dynamo-metamorphic rocks (Figs. 2.3; 2.4). Most likely, the globules were small rounded sand grains brought into marine sediments by ancient sandstorms (Belyaev, 2018; Belyaev and Yukhalin, 2021).

In microquartzites $\mathrm{Mk}-1$ and in sericite schists, several varieties of hexahedral or pentahedral structures occur differing in size, internal structure, and mineral composition of pseudomorphs. Possibly, these microfossils were different species of ancient microorganisms having outer protein coats in the form of polyhedrons with icosahedral symmetry (Belyaev, 2018). They are associated with silificated and ferruginizated microfossils of amoebas, cyanobacteria, diatoms, foraminifers, flagellates, and multicellular organisms. Inside the contours, the virus-like structures are composed of microquartzite (Mk-0) formed during cilicification of intracellular cytoplasm or a quartz-hematite aggregate (Q-Hem) containing from 10 to $30 \%$ hematite grains. The quartz-hematite aggregate has a specific symplectic structure of intergrowth of two mineral phases formed as a result of simultaneous crystallization of silica gel and colloidal solution of iron hydrates. Almost all virus-like structures are surrounded by layers of microquartzites (Mk-0) which formed on silificated mucous membranes of cells (Belyaev, 2018). 
Thus, the pentahedral zonal virus-like structure (VS) in the sericite schist (SS) is associated with the globules-grains (Gl) of microquartzite (Fig. 3.1). It has a central rounded formation composed of a quartz-hematite aggregate (Q-Hem) surrounded by a zone of brown microquartzite with rare hematite phenocrysts. VS is also bordered by a zone of light microquartzite (Mk-0) formed during cilicification of the outer mucous membrane of the cell. There are also larger hexagonal structures $1 \times 1.5 \mathrm{~mm}$ (Fig. 3.2) composed of a quartz-hematite aggregate (Q-Hem) and surrounded by a shell of pink microquartzite (Mk-0). This structure has a well-defined rounded formation similar to a nucleus $0.18 \mathrm{~mm}$ across replaced by hematite. In some cases, VS of a complex shape occur surrounded by a pink microquartzite (Mk-0) shell, which may indicate the onset of cell division (Fig. 3.3).
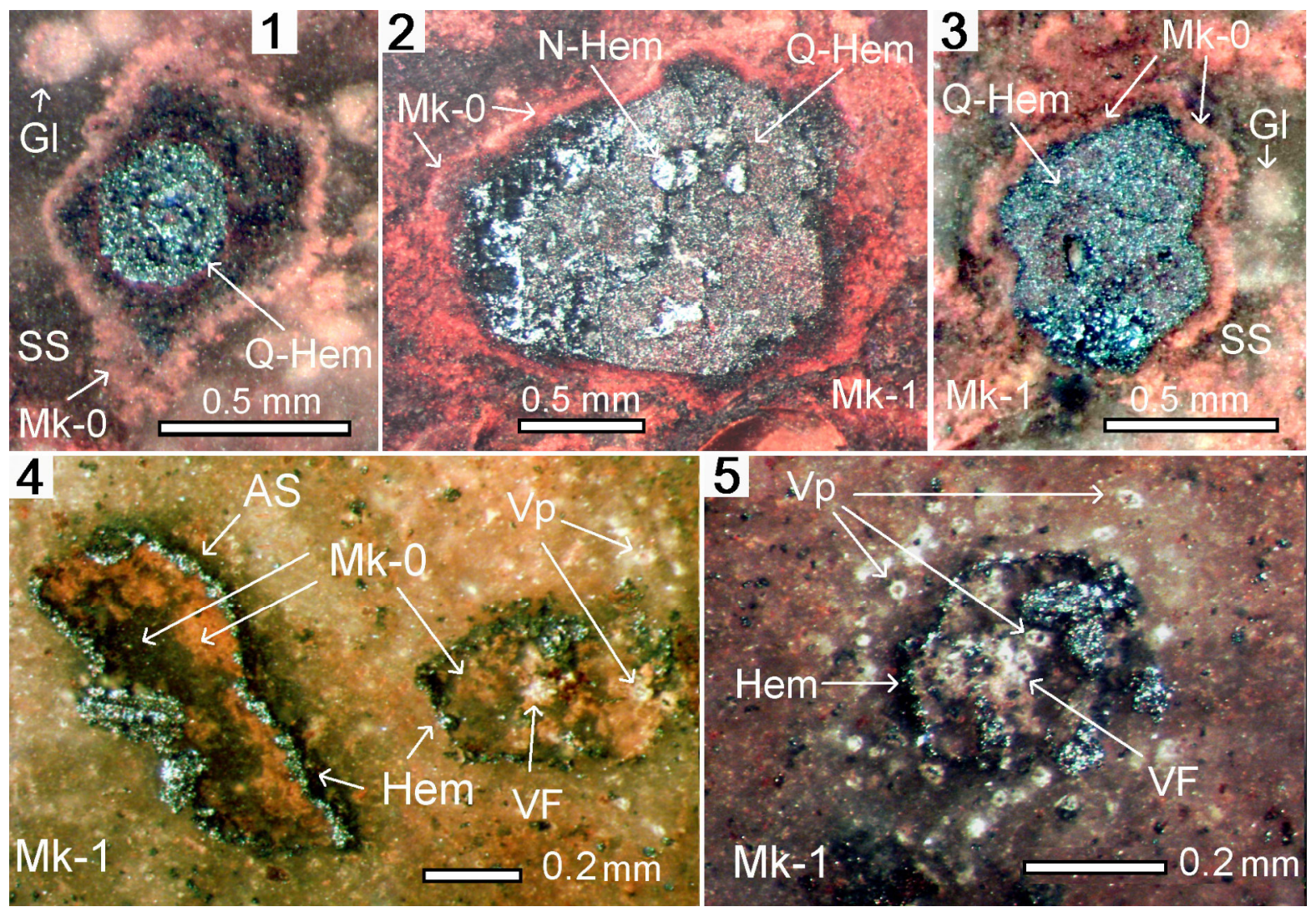

Fig. 3. Virus-like structures (VS) in microquartzites (Mk-1) and sericite shales (SS) from rhyolites. Polished specimens. Scale ruler $-0.5 \mathrm{~mm}(500 \mathrm{mkm})$.

3.1. Pentahedral VS zonal structure in the sericite schist (SS), surrounded by microquartzite on the mucous membrane. The Central part is composed of quartz-hematite aggregate (Q-Hem). At the top left, the globules (Gl);

3.2. Hexahedral VS structure in microquartzites (Mk-1) composed of quartz-hematite aggregate (Q-Hem), and surrounded by microquartzite on the mucous membrane (Mk-0). In the upper part VS structure, you can see a clearly defined rounded nucleus-like structure, composed of hematite (Hem);

3.3. VS complex-shaped structure, in microquartzites (Mk-1) and sericite shale (SS), surrounded by microquartzite on the mucous membrane (Mk-0). Perhaps this is the beginning of «cellular division»;

3.4. Virus-like structure (VS) in association with Amoeba-like Structures (AS) in microquartzites (Mk-1). The contours of microfossils are composed of chains of hematite grains (Hem). Inside VS and in surroundings groundmass is oval zonal formations similar to virophages (VP), composed of light gray fine-grained microquartzite. In the center of the VS is formation, a similar to the «virus factory» (VF); 
3.5. Hexagon section VS with contours, folded chains of hematite grains. Inside the structure and in environment groundmass are oval zonal formations similar to virophages (VP). In the Central part is available formation is similar to the «virus factory» (VF).

Virus-like hexagonal structures in microquartzites (Mk-1) are often associated with amoebalike structures (AS) (Fig. 3.4). The contours of microfossils are composed of chains of small hematite grains (Hem) which, most likely, formed during crystallization of iron hydroxides adsorbed on the surface of shells and membranes. Small (up to $0.01 \mathrm{~mm}$ ) zonal oval formations composed of light grey fine-grained microquartzite are found inside and in the immediate environment of virus-like structures (Figs. 3.4; 3.5.). Possibly, these are silificated viral particles of the most ancient obligate superparasites similar to virophage Sputnik (Vp) coexisting with mimiviruses (La Scola, et al., 2008).

\section{microorganisms \\ 4.3. Microfossils of virus-like structures in association with multicellular}

Multicellular organisms are those that consist of two or more specialized types of cells. They occur as a result of the division of the mother cells. But, in the initial stage of division, only one type of cell is formed, called blastomeres. Microquartzites and sericite aggregates contain structures that can be interpreted as microfossils of blastomeric cells of multicellular microorganisms (microfossils of multicellular microorganisms - MMM). They are represented by linearly elongated (Figs. 4.1; 4.2), or diamond-shaped four-cell formations (Fig. 4.3).

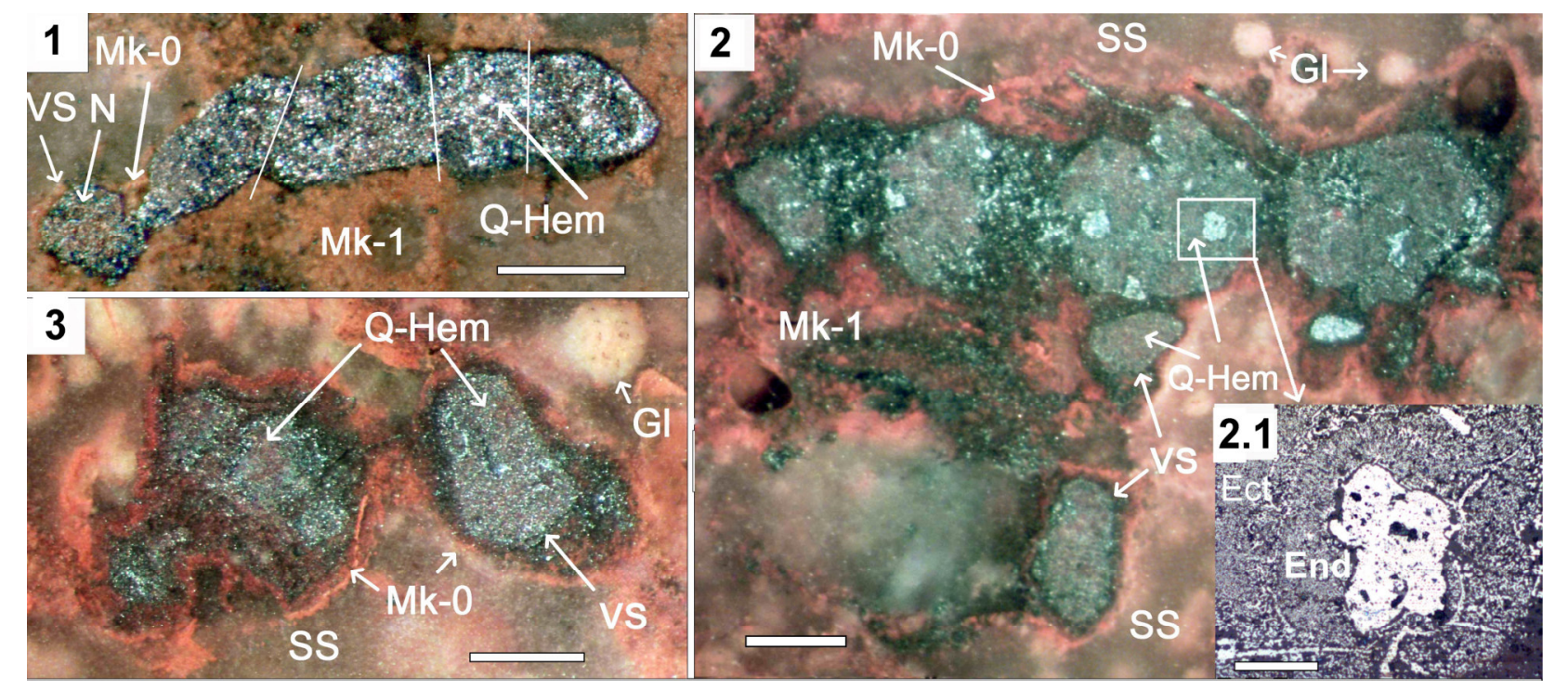

Fig. 4. Virus-like structures (VS) in microquartzites (Mk-1) and sericite shales (SS) from rhyolites in association with multicellular microorganisms. Polished specimen's. Scale ruler -0.5 $\mathrm{mm}(500 \mathrm{mkm})$.

4.1. Linearly elongated four-section microfossils of multicellular microorganisms (MMM) in microquartzite, in contact with hexagonal VS. Inside VS is a rounded nucleus-like structure $(\mathrm{N})$.

4.2. A linearly elongated four-cell MMM structure in the sericite shale (SS), composed of quartz-hematite aggregate (Q-Hem), and surrounded by microquarcite on the mucous membrane (Mk-0). In the central «cell» there are two distinct rounded formations, similar to nucleus-like structure, composed of hematite (Hem). In Association with MMM, there are three oblong hexagons VS composed by a quartz-hematite aggregate (Q-Hem). In the sericite shale (SS) are globules (Gl).

4.2.1. Formation of a nucleus-like structure composed of hematite. It is surrounded by a quartz-hematite aggregate with a symplectic structure (Q-Hem) formed by the endoplasm (End) and ectoplasm (Ect) of the cell. Light grey hematite, dark grey quartz. In reflected light with an analyzer. Ruler 100 microns. 
4.3. Diamond-shaped MMM in sericite shale (SS) in Association with oblong hexahedral VS. Both structures are composed of quartz-hematite aggregate (Q-Hem) and surrounded by microquartzites (Mk-0). At the top right is globule (Gl).

One of the MMM is in direct contact with the hexahedral virus-like structure VS, which has a rounded nucleus-like formation (Fig. 4.1). Outside, MMM and VS are surrounded by a common siliceous shell. Supposedly, this virus-like structure "attacked" the multicellular structure. Or vice versa, the primordial multicellular predator animal "attacked" a virus-like eukaryotic cell.

The inner parts of the MMM are composed of a quartz-hematite aggregate with a symplectic texture. One of the MMM "cells" (Fig. 4.2.) contains a nucleus-like formation composed of hematite and surrounded by a quartz-hematite aggregate with a symplectic texture (Q-Hem) formed by the distinct endoplasm (End) and ectoplasm (Ect) of the cell (Fig. 4.2.1). In direct contact with MMM, oblong hexahedral virus-like structures are found (icosahedral capsids of viruses, elongated along the axis of symmetry of the fifth order, are called oblong) (Figs. 4.2; 4.3.). VS are also composed of a quartz-hematite aggregate (Q-Hem) with a symplectic texture. A diamond-shaped MMM in sericite schist (Ser) is surrounded by a siliceous shell together with an oblong hexahedral VS. A microquartzite globule (Gl) is on the upper right (Fig. 4.3).

\subsection{Virus-like structures with "tails"}

Some VS varieties with hexahedral outlines (presumably cross-sections of protein shells with icosahedral symmetry) have saccular formations, "tails" (Tl), together with which they are surrounded by siliceous shells (Figs. 5.1; 5.2; 5.3; 5.4). 

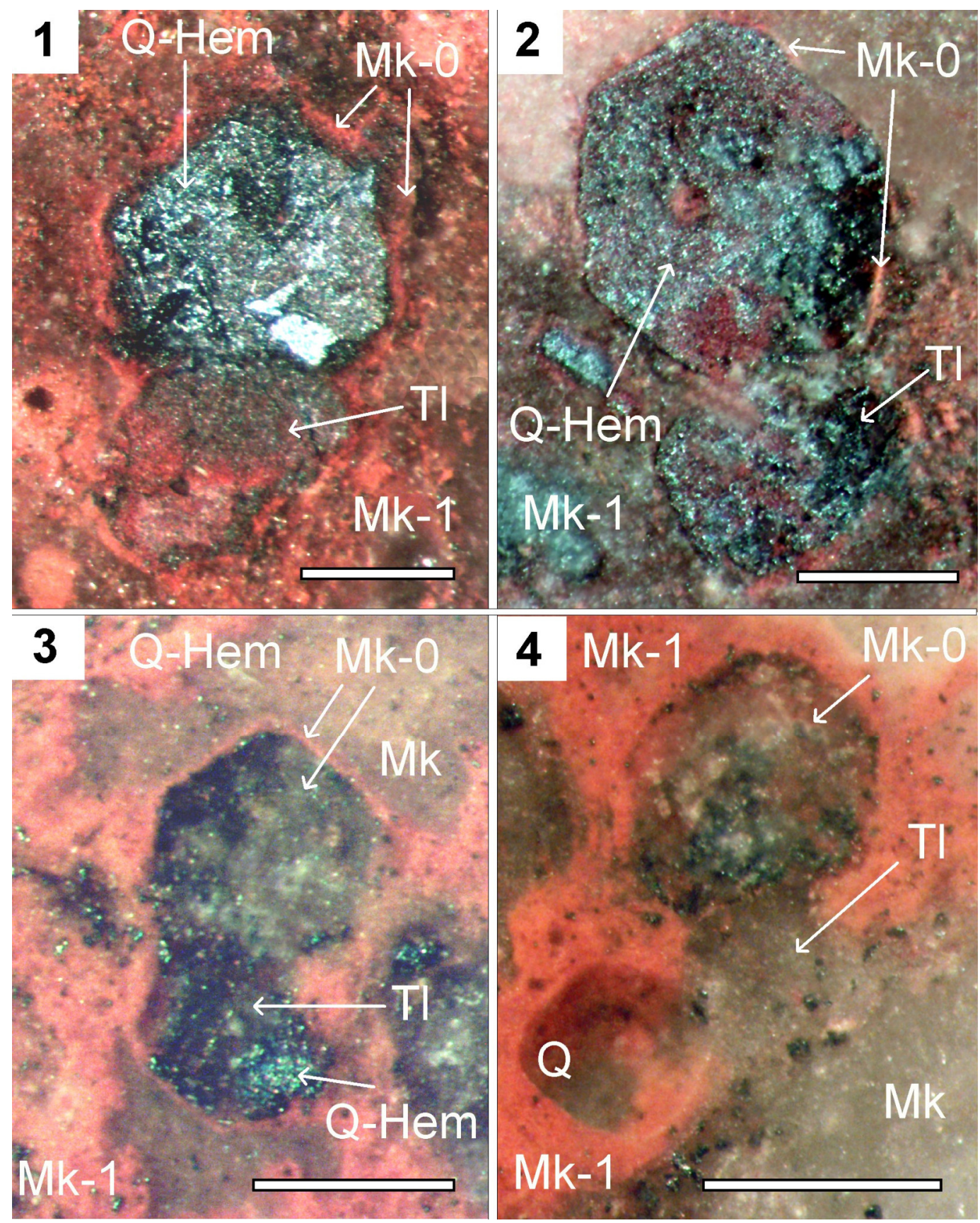

Fig. 5. Virus-like structures (VS) in microquartzites (Mk-1) and sericite shales (SS) from rhyolites. Polished specimen's. Scale ruler - $0.6 \mathrm{~mm}(600 \mathrm{mkm})$.

5.1. Large VS structure in microquartzite (Mk-1), composed of quartz-hematite aggregate, and together with saccular-like formation $(\mathrm{Tl})$, surrounded by microquartzites on the mucous membrane (Mk-0).

5.2. Large VS structure in microquartzite (Mk-1), composed of quartz-hematite unit, and together with saccular-like formation ( $\mathrm{Tl}$ ), surrounded by microquartzites on a on the mucous membrane (Mk-0).

5.3. Average VS (D.h.) with a saccular-like formation ( $\mathrm{Tl}$ ) in microquartzites, composed of finer-grained microquartzite (Mk-0).

5.4. Average VS (D.h.) with a saccular-like formation (Tl) in microquartzites composed of finer-grained microquartzite (Mk-0).

According to the morphology and size of the "capsids", they can be divided into two groups: large virus-like structures $0.8-1 \mathrm{~mm}$ in diameter, composed by a quartz-hematite aggregate with a symplectic texture (Figs. 5.1; 5.2), and medium virus-like structures $0.5 \mathrm{~mm}$ across (Figs. 5.3; 5.4). 
Medium VS are tentatively assigned to a single species with the conventional name Dinovirus hoglandi (D.h.).

Large hexahedral VS structures in microquartzite Mk-1 (Figs. 5.1; 5.2), formed during the replacement of the mucous substance of the biofilms, are composed of a quartz-hematite aggregate (Q-Hem) with a symplectic texture, and together with tail formations (Tl) are surrounded by microquartzite (Mk-0) formed by replacing the mucous membrane of cells.

Medium VS with "tails" (Tl) in microquartzites Mk-1 (Figs. 5.3; 5.4) are composed of finergrained microquartzite (Mk-0) with rare hematite phenocrysts. D.h. "head" fragment is observed in direct contact with an amoeba-like structure (Fig. 6.1). Supposedly, this is pseudomorphosis on the remains of the VS protein coat that has invaded the amoeba cell.
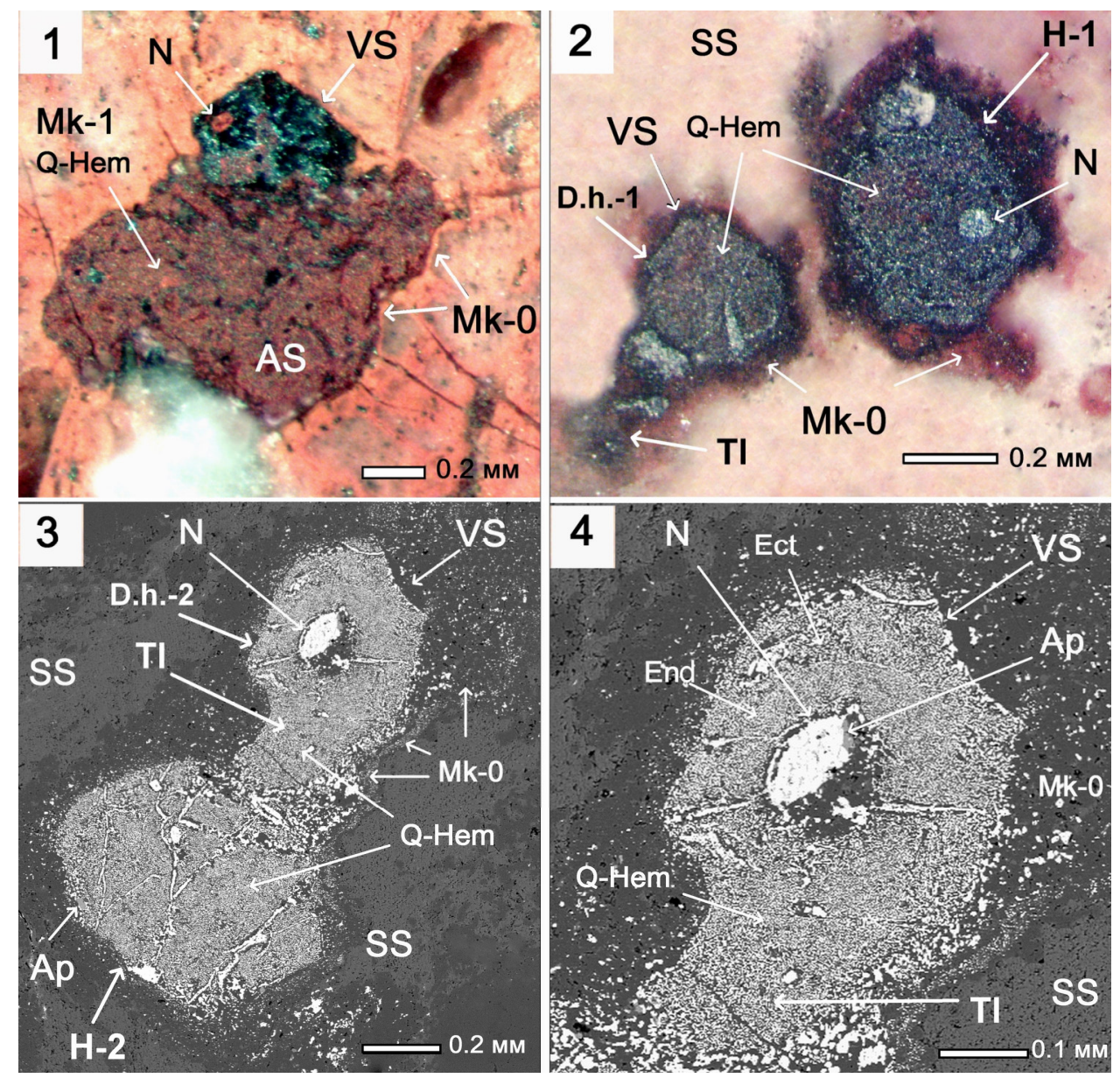

Fig. 6. Microfossils of the virus-like structure of Dinovirus hoglandi, in the microquartzites and sericite schist. Scale ruler $-0.2 \mathrm{~mm}$.

6.1. A fragment of the «head» of the Dinovirus hoglandi, replaced by quartz and hematite, in contact with an amoeboid structure (AS), composed of microquartzite with hematite, in the microquartzites. Polished specimen.

6.2. Dinovirus hoglandi (D.h.-1) in the sericite schist (SS), with a saccular-like formation (Tl) in «contact» with the hexagon-cell structure $\mathrm{H}-1$. Both structures are composed of a quartz-hematite aggregate and surrounded by microquarcite on the mucous membrane (Mk-0). The H-1 structure has a rounded nucleus-like structure, composed of hematite (Hem). Thin section, without the analyzer.

6.3. Dinovirus hoglandi (D.h.-2) with a saccular-like formation (Tl) in «contact» with the hexagon-cell structure H-2. Both structures are composed of a quartz-hematite aggregate (Q-Hem) with a symplectic structure, and are surrounded by microquartzites with rare hematite inclusions (MK $+\mathrm{Hem})$. At the edge of the H-2 structure is a prismatic grain of Apatite (Ap). Micro photo of a polished specimen, on a JSM-7510LA scanning electron microscope in reverse-reflected electrons. 
6.4. Detail of the virus-like structure D.h.-2 (6.3). In the center of the hexagon-cell head, a rounded nucleus-like structure is surrounded by a quartz-hematite aggregate, that replaces the endoplasm (End) and ectoplasm (Ect) of «cell». The nucleus-like structure is composed of hematite and quartz, with a grain of Apatite (Ap) between them.

Dinovirus hoglandi virus-like structures with "tail"-like formations are also found in sericite schists and, in these cases, are composed of a quartz-hematite aggregate with a symplectic texture (Figs. 6.2; 6.3; 6.4). The photo of a transparent polished section without an analyzer (Fig. 6.2) shows that D.h.-1 structure with a "tail" (Tl) is in close "contact" with the hexahedral "cell" H-1. Both structures are composed of a quartz-hematite aggregate and are surrounded by a common siliceous shell (Mk-0). The hexahedral structure of $\mathrm{H}-1$ has a rounded nucleus-like formation composed of hematite (Hem).

Backscattered electron photomicrograph on a JSM-7510LA scanning electron microscope shows that D.h.-2 with a "tail" (Tl) is also in direct contact with the hexahedral "cell" H-2 (Fig. 6.3). Both structures are composed of a quartz-hematite aggregate (Q-Hem) with a symplectic texture and are surrounded by a common microquartzite shell (Mk-0). This pattern can be interpreted as an attack by a virus-like parasitic cell on a hexahedral cell. The edge of the hexahedral "cell" H-2 contains a prismatic apatite grain (Fig. 6.3). In the centre of the hexahedral head of D.h.-2 (possibly, a cross-section of the protein coat with icosahedral symmetry) there is an oval formation similar to the nucleus, and the virus-like structure with a "tail" was, apparently a eukaryote. The nucleus is composed of hematite and quartz and is surrounded by a quartz-hematite aggregate that has replaced the endoplasm (End) and ectoplasm (Ect) of the virus cell. There is an apatite grain (Ap) in the nucleus between quartz and hematite (Fig. 6.4).

5. Mineral residues of nucleotides phosphates in microfossils of eukaryotes and virus-like structures

Unity of the biological world is determined by the obligatory presence in all living things of organic compounds of phosphorus, nucleoside phosphates, which they should have inherited from ancient microorganisms. However, there is no reliable material evidence of this so far. Apatite grains found in the mineralized cytoplasm of some microfossils eukaryotic and virus-like structures (Belyaev and Yukhalin, 2021) could have formed during them fossilization from phosphoric acid residues of the decayed ATP, RNA, and DNA nucleotides. During thermal cilicification at temperatures above one hundred degrees Celsius, the substance of microorganisms, protoplasm, shells, and membranes, decomposed into water, carbon and nitrogen oxides, which were removed from the fossilization area in a gaseous state. In this case, calcium ions and phosphate residues, which were part of the nucleoside phosphates of ATP, RNA, and DNA, remained almost at the site of cilicification (within the volume of microfossils). Phosphate ions and calcium ions bound to form $\mathrm{Ca}_{5}\left(\mathrm{PO}_{4}\right)_{3}$ apatite. In modern eukaryotes, ATP contains $18.5 \%$ phosphorus, and, on average, accounts for $0.04 \%$ of the cell's wet weight, while nucleic acids contain about $10 \%$ phosphorus (Laura; et al., 2008). Thus, knowing the size of apatite grains in the nuclei and mineralized cytoplasm of microfossils of virus-like structures and eukaryotes, it is possible for the first time to approximately calculate the mass of the primary source of phosphorus, ancient ATP, RNA, and DNA nucleoside phosphates (Belyaev, Yukhalin, 2021).

Apatite grain in a hexahedral cell H-2 (Fig. 6.3) with visible dimensions of $13 \times 25 \mu \mathrm{m}$, most likely, is a longitudinal section of a crystal of a hexagonal prism. It should be borne in mind that the observed crystal section is a special case and the real grain size of apatite can be even larger. The estimated volume of apatite grain could be about $10,000 \mu \mathrm{m}^{3}$, and at apatite density of $3.2 \mathrm{~g} / \mathrm{t}$, the grain weight would be $32,000 \mathrm{pg}$, apatite contains $19 \%$ phosphorus, so it contained, respectively, $6,080 \mathrm{pg}$ of phosphorus. The source of this phosphorus could be both the decomposed nucleoside phosphates of ATP and the DNA and RNA of the genome. By calculation, we may estimate approximately how much phosphorus could be found in ATP and in the genome containing DNA and RNA. 
Volume of the icosahedron of the hexahedral cell $\mathrm{H}-2$ is about 60 million $\mu \mathrm{m}^{3}$. If the cytoplasm density is close to the density of water $1 \mathrm{pg} / \mathrm{\mu m}^{3}$, the cell could have a mass of about 60 million pg. If $\mathrm{H}-2$ cell (like modern cells) contained $0.04 \%$ ATP, then its mass would be $24,000 \mathrm{pg}$. ATP contains $18.5 \%$ phosphorus, i.e., the cell could contain 4,500 pg. However, apatite grain contains $6,080 \mathrm{pg}$ of phosphorus, and, therefore, the remaining 1,580 pg could belong to the DNA and RNA of the cell genome. If during the crystallization of apatite it included phosphorus from the phosphoric acid residues of decayed DNA and RNA containing about $10 \%$ phosphorus, then the mass of the latter could be $15,800 \mathrm{pg}$, or about 15,800 $\mathrm{Gb}$ billion base pairs (a nucleotide with a mass of 1 pg contains 978 million base pairs).

Apatite grain in the D.h.-2 "nucleus" (Fig. 6.4) has a size of approximately 30x30x6 $\mu \mathrm{m}$ and a volume of $5,400 \mu \mathrm{m}^{3}$. At a density of $3.2 \mathrm{~g} / \mathrm{cm}^{3}$, apatite contains $19 \%$ phosphorus, i.e., $3,200 \mathrm{pg}$ (1 picogram $\left.(\mathrm{pg})=10^{-12} \mathrm{~g}\right)$. However, the source for this phosphorus could be not only the RNA and DNA of the decayed genome, but also the ATP nucleoside phosphate. If we assume that the "head" of the D.h. structure had icosahedral symmetry, its volume was approximately 16 million $\mu \mathrm{m}^{3}$ (excluding the volume of the "nucleus" 1 million $\mu \mathrm{m}^{3}$ ). At a cell cytoplasm density of $1 \mathrm{pg} / \mu \mathrm{m}^{3}$ $\left(1 \mu \mathrm{m}^{3}\right.$ of water has a mass of 1 picogram, $10^{-12} \mathrm{~g}$ ), the mass of the "head" of the Dinovirus hoglandi structure could be equal to 16 million $\mathrm{pg}$, and the cytoplasm of the virus-like cell could contain $6,400 \mathrm{pg}$ ATP. With a content of $18.5 \%$ phosphorus in ATP, cell cytoplasm could contain 1,184 pg of phosphorus. But a grain of apatite contains $3,200 \mathrm{pg}$ of phosphorus, and, therefore, the remaining $2,020 \mathrm{pg}$ could belong to the DNA and RNA of the cell genome. Consequently, if apatite crystallized from phosphoric acid residues of the decayed genome of DNA and RNA, containing about $10 \%$ phosphorus, then the mass of the latter could be $20,200 \mathrm{pg}$, or about $20,600 \mathrm{~Gb}$ billion base pairs. Even considering a significant error when calculating the volume of apatite grain in the nucleus of a virus-like cell, the genome size can be even larger. Firstly, the true grain size of apatite can significantly exceed the size of the observed crystal cross-section, and, secondly, in the mineralforming medium (limited by the cell volume), there may be a certain amount of scattered phosphorus, which remained after the end of the mineral crystallization.

D.h. genome size seems unrealistically huge. For comparison, the human genome contains $3.2 \mathrm{~Gb}$ base pairs, and the largest known genome of living organism at the moment is Amoeba dubia $\mathrm{C}=670 \mathrm{~Gb}$ (200 times more than the human genome).

\section{Principle of genomic-nuclear proportionality}

At the same time, the size of the eukaryotic cell genome can be estimated in another independent way. Thus, in accordance with the skeletal DNA model (Cavalier-Smith, 2005), the volume of the nuclei of modern eukaryotes is determined by the size of DNA and RNA contained in the nucleus: the larger the size (molecular weight) of the genome, the larger the size of the nucleus it requires. That is, knowing the volume of the nucleus $\mathrm{V}^{\mathrm{N}}$ of microfossil eukaryotes, one can solve the inverse problem and indirectly determine the size (mass) of the $\mathrm{C}$ genome by the formula: $\mathrm{C}=$ $\mathrm{V}^{\mathrm{N}} / \mathrm{Kc}$, where $\mathrm{Kc}$ is the proportion factor. If we assume that the proportionality of the relationship between the volume of the nucleus and the size of the genome is of a physical nature and is inherited by unicellular eukaryotes from the earliest stages of their evolution, then the proportion factor can be calculated from the ratio of the volumes of nuclei and masses of genomes in modern unicellular eukaryotes. Thus, according to the literature, for eukaryotes with different genome weights: Amoeba proteus $(\mathrm{C}=290 \mathrm{pg})$, Amoeba dubia $(\mathrm{C}=680 \mathrm{pg})$ and Saccharomyces cerevisiae yeast $(\mathrm{C}=1.2 \mathrm{pg})$ proportion factor $\mathrm{Kc}\left(\mathrm{V}^{\mathrm{N}} / \mathrm{C}\right.$ ratio) on average is about 50 .

If we use the principle of genomic-nuclear proportionality to estimate the size of D.h.-2 genome, then for a nucleus volume of $1,000,000 \mu \mathrm{m} 3$, with $\mathrm{Kc}=50$, the value of $\mathrm{C}$ genome would be $20,000 \mathrm{pg}$, which almost coincides with the value of 20,200 pg obtained by calculations for apatite.

Genome masses in other microfossils of virus-like structures as well as in eukaryotes: flagellates, foraminifers, and multicellular microorganisms, estimated both by the incorporated apatite grains and by the size of the nuclei, also amounted to tens of thousands pg (Belyaev and Yukhalin, 2021). 


\section{Discussion of the results}

Favorable environmental and geochemical conditions and an abundance of biophilic elements were necessary for the existence of huge genomes in ancient virus-like microorganisms. Chemical composition of seawater in the Paleoproterozoic, as in modern seas and oceans, was characterized by low concentrations of potassium and phosphorus, which limit the quantitative and qualitative development of life. Phosphate ion content in seawater is the main factor limiting the growth and reproduction of microorganisms (Diaz, et al., 2008; Paytan, et al., 2007). Without phosphorus, the synthesis of nucleoside phosphates and proteins, i.e., life in general, is impossible! In the Paleoproterozoic, phosphorus entered the water of sea basins mainly from tholeiitic, essentially sodium basalts widespread on the ocean floor, while in the continental high-potassium basalts of Hogland, the phosphorus content was more than three times higher (Belyaev, 2018). Therefore, in the Hogland epoch, the water of the Abel Sea could be significantly enriched in phosphate ion.

Potassium is also an essential biophilic chemical element that limits the growth and reproduction of microorganisms. It provides the necessary osmotic pressure in biological fluids and maintains the electrical potential on the cell membranes, keeping the internal environment constant. As shown earlier (Belyaev, 2013; Belyaev, 2018), waters of the inland sea were enriched in potassium by a factor of five or more due to the fluid action of high-K basaltic and granite magmas.

Moreover, more than $90 \%$ of seawater radioactivity is caused by the radioactive isotope ${ }^{40} \mathrm{~K}$ with a half-life of $\mathrm{T}^{1 / 2}=1.3 \cdot 10^{9}$ years. ${ }^{40} \mathrm{~K}$ content in the natural mixture of isotopes 1,640 million years ago was 2.3 times higher than at present, and its concentration in seawater was at least five times higher. Therefore, the radiation background in seawater at that time could exceed the modern level by an order of magnitude. In this case, ${ }^{40} \mathrm{~K}$ concentrated inside the cells in the immediate vicinity of DNA and, during its radioactive decay, $\beta$-particles and $\gamma$-quanta of ionizing radiation caused spontaneous mutagenesis, which largely determined natural selection and new speciation.

Accumulation of photosynthetic phytoplankton in the mucous substance of biofilms should have led to their significant enrichment with free oxygen. This is indirectly confirmed by the fact that microquartzites (Mk-1) formed during the silicification of the mucous substance of biofilms have a characteristic reddish-brown color due to the presence of the smallest admixtures of iron oxides. In addition, during fossilization and ferruginization of eukaryotic microorganisms, a lot of free oxygen was required to oxidize ferrous iron and form quartz-hematite aggregate containing up to $30 \%$ hematite.

Thus, the increased concentrations of biogenic elements: potassium, phosphorus, carbon, and nitrogen oxides, as well as the radioactive isotope ${ }^{40} \mathrm{~K}$ in seawater during underwater eruptions of high potassium magmas could contribute to the evolutionary development of virus-like eukaryotes and multicellular microorganisms with huge genomes.

It is known that in all living organisms the bulk of DNA is represented by non-coding sequences. For example, the non-coding parts of genes in the human genome account for about $97 \%$ of the genome mass (Lander et al., 2001). According to the model of Minkevich and Patrushev noncoding sequences of eukaryotic genomes can perform a protective (reserve) function against nucleotides of the coding part damaged by mutagens (Minkevich and Patrushev, 2007).

Huge genomes of ancient microorganisms, also, most likely, contained mainly non-coding gene sequences and were in constant contact with endogenous mutagens arising in redox reactions, when exposed to cosmic ionizing radiation as well as during the decay of the radioactive isotope

${ }^{40} \mathrm{~K}$. Free radicals and streams of ionizing radiation permanently damaged genomic DNA, and noncoding gene sequences could play the role of a reserve that protects the vital activity of cells from the effects of mutagens from the environment.

Favorable geoenvironmental conditions associated with the intrusion of high-potassium granites of the rapakivi complex and the influx of hydrothermal fluids with biophilic chemical elements into seawater could persist for a long time. Thus, the Wiborg complex of rapakivi granites with an exposed area of about $20,000 \mathrm{~km}^{2}$ and a massif thickness of up to ten $\mathrm{km}$ could cool down over millions of years. At the same time, along the periphery of the Baltic-Ladoga geoblock, during 
the intraplate granite magmatism of the Hoglandian time of 1,640-1,500 Ma, formation of two dozen rapakivi granite massifs continued accompanied by the formation of volcanic and hydrothermal altered rocks (Larin, 2011). All this time, an inland sea basin could be located in the geoblock area, preserving favorable geoenvironmental conditions.

However, after the end of the Hoglandian time in the young part of the Baltic Shield and the cessation of the inflow of hydrothermal fluids with biophilic chemical elements, potassium could be quickly depleted from seawater by clayey sediments, and phosphorus was absorbed by microorganisms, and, after their dying away, also deposited in sediments at the basin floor. This could contribute to the extinction of ancient planktonic microorganisms, or to their subsequent evolutionary transformation and adaptation to an environment poor in biophilic elements. It can be assumed that favorable environmental and geochemical conditions in the continental Abel Sea played the role of a kind of springboard in the evolution of the primordial planktonic microorganisms.

Intraplate alkaline magmatism of the rapakivi formation had a local nature but was manifested in 35 complexes on platforms of all continents in the interval from 2,800 to $500 \mathrm{Ma}$ (Larin, 2011). In some cases, it was accompanied by the formation of volcanic, hydrothermal, and chemogenic-sedimentary silicate and carbonate rocks (Belyaev, 2018). Therefore, favorable geoenvironmental conditions associated with underwater high-potassium granite magmatism, like the Hoglandian time, could manifest themselves widely and for a significant time, and, in general, considerably affect the evolution of the Earth's biosphere.

\section{Conclusion}

The data obtained suggest another scenario for the transformation of ancient virus-like structures into obligate parasites. Dinoviridae incertae sedis eukaryotes were large facultative parasitic cells and could reproduce by division. They attacked other microorganisms, most likely, to consume their proteins, ATP, and DNA. At the same time, the DNA and RNA of the genome of the parasitic cell could partially move into the cytoplasm and into the nucleus of the attacked cell, in which the nucleotides of the virus-like structures were replicated, and new viral particles appeared. Over time, as a result of natural selection, the processes of own division of parasitic cells lost their significance, and after their termination, the structures turned into viruses, full-fledged obligate parasites. Possibly, supergiant virus-like structures from the group of unclear systematic position of Dinoviridae Incertae sedis were representatives of an extinct family of unicellular facultative parasites or were the ancestors of giant viruses of the Mimiviridae family. Along with virus-like eukaryotes, the primordial viruses already existed, obligate super parasites, similar to the virophages satellites of mimiviruses.

\section{Acknowledgements}

We would like to thank my colleagues for technical support: Prof. Krivovichev V.G., Prof. Prasolov E.M., Dr. Bogdanov Y.B., Dr. Polekhovski Y.S., Dr. Galankina O.L., MSc. Putinseva L.V., MSc. Kobilkov S.V. and his colleagues.

\section{References}

1. Abergel C., Legendre M., Claverie J.M. The rapidly expanding universe of giant viruses: Mimivirus, Pandoravirus, Pithovirus and Mollivirus. FEMS Microbiol. Rev. 2015; 39(6): pp. 779796.

2. Arslan, D.; Legendre, M.; Seltzer, V.; Abergel, C.; Claverie, J.-M. (2011). Distant Mimivirus relative with a larger genome highlights the fundamental features of Megaviridae. Sciences. 2011. Vol. 108. No. 42, pp. 17486-17491. doi:10.1073/pnas.1110889108.

3. Belyaev A. M., Bogdanov Y.B., Levchenkov O.A. Petrogenesis of the bimodal rapakivi-related volcanites of the Island of Hogland, $1.64 \mathrm{Ga}$ Wiborg batholith, Russia //International Field Conference: Proterozoic Granite System of the Penokean Terrane in Wisconsin, Madison, Wisconsin, USA, 1998, pp.139-140. 
4. Belyaev A.M. Petrology of volcanic rocks from the rapakivi formation (Island Hogland) 2013. J. Regional Geology and Metallogeny, St. Petersburg, Russia, N 55. pp. 28-36 (in Russia).

5. Belyaev A.M. Role of viruses in the evolution of the earth's early biosphere //Geology, Geoecology, and evolutionary geography. V. XVI. Saint Petersburg, 2017, pp. 25-28 (in Russia).

6. Belyaev A.M. Paleoproterozoic Underwater Volcanism and Microfossil-Like Structures in the Metasedimentary Siliceous Rocks (Hogland Island, Russia) // Journal of Earth Science, 2018; Vol. 29, No. 6, pp. 1431-1442, doi.org/10.1007/s12583-018-0883-4.

7. Belyaev A. M., Yukhalin P. V. Phosphate residues of nucleotides in the microfossils from the Paleoproterozoic eukaryotes //Geology, Geoecology, and Evolutionary Geography. Vol. XVII. SPb., 2018. pp. 45-49 (in Russia).

8. Belyaev, A.M. Perspectives for the study of microfossils in volcanic-sedimentary siliceous rocks of Paleoproterozoic//Proceedings of the LXIV session of the Paleontological society, Ed. PIN RAS, Moscow, 2019, Vol. 2. p. 28-43 (in Russia).

9. Belyaev A. M. Paleoviruses//Proceedings of the LXV session of the Paleontological society, 2019, vol. 1. pp. 28-31 (in Russia).

10. Belyaev A.M. Yukhalin P. V. Evolution of eukaryotic genomes (based on the results of the study of paleorproterozoic microfossils) //Proceedings of the LXIV session of the Paleontological society, 2020, pp. 18-21 (in Russia).

11. Belyaev A.M., Yukhalin P.V. Sizes of Genomes of Paleoproterozoic Microfossil Eukaryotes. Int. J. Paleobiol\&Paleontol 2021, 4(1): 000121. https://doi.org/10.23880\%2Fijpbp16000121.

12. Canchaya C., Fournous G., Chibani-Chennoufi S., et al. Phage as agents of lateral gene transfer. Curr. Opin. Microbiol, 2003, 6 (4): pp. 417-24. doi:10.1016/S1369-5274(03)00086-9.

13. Cavalier-Smith, T. Economy, speed and size matter: evolutionary forces driving nuclear genome miniaturization and expansion. Ann. Bot. (Lond.) 2005, 95, pp. 147-175.

14. Diaz J., Ingall E., Benitez-Nelson C., et al., Marine Polyphosphate: A Key Player in Geologic Phosphorus Sequestration//Science, 2008, V.320. P. 652-655, doi: 10.1126/science. 1151751.

15. Jônatas Abrahão et al., Tailed giant Tupanvirus possesses the most complete translational apparatus of the known virosphere/ Nature Communications 2018, volume 9, Article number: 749, doi:10.1038/s41467-018-03168-1.

16. Laidler, J. R., \& Stedman, K. M. Virus silicification under simulated hot spring conditions. Astrobiology, 2010; (6), pp. 569-576. Russia).

17. Larin A.M. Rapakivi Granites and associated rocks, Moscow, Nauka, 2011, 403 p. (in

18. Legendre M., Arslan D., Abergel C., et al. Genomics of Megavirus and the elusive fourth domain of Life // Commun Integr Biol. 2012. B. 1. T. 5. pp. 102-106.

19. La Scola B., Desnues C., Pagnier I., et al. The virophage as a unique parasite of the giant mimivirus //Nature. 2008. T. 455. pp. 100-104. doi:10.1038/nature07218-PMID 18690211.

20. Minkevich, L.I., Patrushev, L.I. Non-Coding genome sequences and the size of the eukaryotic cell nucleus as essential factors for protecting genes from chemical mutagens //Bioorganic chemistry, 2007, Vol. 33, N 4, pp. 474-477 (in Russia).

21. Paytan A., McLaughlin K. (2007) The Oceanic phosphorus cycle. Chemical Reviews 107(2): 563-576. 